\section{Susceptibility of Evergreen Azalea Cultivars to Anthracnose Caused by Colletotrichum acutatum}

\author{
Domenico Bertetti, M. Lodovica Gullino, and Angelo Garibaldi ${ }^{1}$
}

ADDITIONAL INDEX WORDs. acid-loving plants, Rhododendron, Ericaceous plants, host plant resistance, disease resistance, susceptibility trials

Summary. Colletotrichum acutatum is the causal agent of anthracnose on azalea (Rhododendron azalea). This disease was observed in Fall 2002 on 'Palestrina' azalea in Italy. Severe outbreaks of this disease were recently observed on several cultivars of azalea grown in nurseries located in the Verbano-Cusio-Ossola Province in the Piedmont region of northern Italy. Information on susceptibility to C. acutatum among azalea cultivars currently grown in Italy was unavailable. Artificial inoculations were performed to evaluate the susceptibility of 70 evergreen azalea cultivars produced in the Lake Maggiore area. Sixty of the cultivars evaluated failed to develop disease symptoms and were considered resistant to C. acutatum. Symptomatic cultivars were placed into three susceptibility classes. The cultivars Addy Wery, Fior di Pesco Cavadini, Geisha Orangerot, Kermesina, Orion, Palestrina, and Snow developed severe anthracnose symptoms. The cultivars Conversation Piece, Eikan, and Martha Hitchcock showed moderate susceptibility.

$\mathrm{R}$ hododendrons (Rhododendron spp.) are popular and economically important ornamental plants in the Ericaceae family and are widely grown in the Piedmont region of northern Italy. The presence of acidic soils provides very favorable growing conditions. In the Lake Maggiore area, the market for acid-loving plants is valued at 13 million euros per year. Azalea is the most popular species grown, accounting for $50 \%$ of total production. More than one million plants are sold each year (Rabbogliatti, 2004), with a portion of the production grown for export.

Azaleas are susceptible to several foliar diseases (Benson and WilliamsWoodward, 2001), including anthracnose, a fungal disease that causes leaf spots and defoliation. Colletotrichum acutatum was identified as the causal agent of anthracnose on azalea in Italy, where, in Fall 2002, the disease was observed on 'Palestrina' azalea

Center of Competence for the Innovation in the Agro-environmental Sector (AGROINNOVA), University of Turin, Via Leonardo da Vinci, 44, 10095 Grugliasco (TO), Italy

We thank Valentina Scariot for group identification of azalea cultivars; Tecnoverde S.r.l., Verbania, Fondotoce (VB), Italy, for technical assistance; Mattia Sanna for statistical advice; and the University of Turin for the research grant

${ }^{1}$ Corresponding author. E-mail: angelo.garibaldi@ unito.it. in several nurseries located in the Verbano-Cusio-Ossola province. The pathogen was isolated from infected leaves and stems. The mycelium produced cylindrical, tapered conidia measuring 4.8 to $7.2 \mu \mathrm{m}$ in length and 11.0 to $22.8 \mu \mathrm{m}$ in width (average, $5.5 \times 15.2 \mu \mathrm{m}$ ) (Garibaldi et al., 2004). Symptoms of this disease appear on both leaves and stems. Leaf lesions are $1 \mathrm{~mm}$ in diameter, irregularly round, dark-brown to black, and generally surrounded by a chlorotic halo. Lesions may coalesce, forming larger, irregular-shaped lesions. The disease causes defoliation of plants. Generally, the lower leaves are the most heavily infected. Brown, longitudinal lesions form along the entire stem.

Anthracnose on azalea was reported for the first time in Florida on swamp azalea (Rhododendron viscosum) and the causal agent was identified as C. azaleae (Ellis and Everhart, 1895). Since 1954, anthracnose on azalea was observed and described in Louisiana, where the causal agent was identified as the conidial stage of Glomerella cingulata, the teleomorph of C. gloeosporioides. A susceptibility trial was carried out on 11 azalea cultivars belonging to the Kurume and Indica groups (Stathis and Plakidas, 1958). Colletotrichum azaleae is now considered synonymous with C. gloeosporioides (Farr et al., 1989; Von Arx, 1957). Severe outbreaks of anthracnose were recently reported on Rhododendron species growing in Sweden and Latvia. In this case, the causal agent of the disease was identified as $C$. acutatum (Vinnere et al., 2002). However, $C$. dematium was also isolated from some of the infected plants (Vinnere et al., 2002).

After the first appearance of anthracnose in 2002, severe outbreaks were observed in Italy on several cultivars of azalea grown in nurseries in the same area where the disease was first observed. There was no information available regarding the susceptibility to anthracnose among azalea cultivars produced and grown in Italy. The objective of this study was to determine levels of resistance to anthracnose among azalea cultivars grown in the Lake Maggiore area.

\section{Materials and methods}

Plant material. The susceptibility of 70 evergreen azalea cultivars to anthracnose was evaluated (Table 1). Most cultivars belonged to the Kurume, Belgian, and Satsuky groups (Galle, 1987). Some of these cultivars are classified differently, following the Italian classification scheme (Scariot, 2006). Plants were supplied by Tecnoverde S.r.l. (Verbania, Fondotoce, Italy). One-year-old plants were grown in 10-cm-diameter plastic pots and arranged randomly in a completeblock design with three single-plant replications per each cultivar. Container substrate was 9 peatmoss : 1 perlite (by volume). The susceptibility trial was repeated twice.

Pathogen and inoculation METHOD. Plants were artificially

\begin{tabular}{llll}
\hline $\begin{array}{l}\text { Units } \\
\begin{array}{l}\text { To convert U.S. to SI, } \\
\text { multiply by }\end{array}\end{array}$ & U.S. unit & SI unit & $\begin{array}{l}\text { To convert SI to U.S., } \\
\text { multiply by }\end{array}$ \\
\hline 29.5735 & $\mathrm{fl} \mathrm{oz}$ & $\mathrm{mL}$ & 0.0338 \\
2.5400 & inch $(\mathrm{es})$ & $\mathrm{cm}$ & 0.3937 \\
1 & micron & ${ }^{\mu \mathrm{m}}$ & 1 \\
$\left({ }^{\circ} \mathrm{F}-32\right) \div 1.8$ & ${ }^{\circ} \mathrm{F}$ & ${ }^{\circ} \mathrm{C}$ & $\left(1.8 \times{ }^{\circ} \mathrm{C}\right)+32$
\end{tabular}


Research Reports

Table 1. Evergreen azalea cultivars resistant to anthracnose incited by Colletotrichum acutatum.

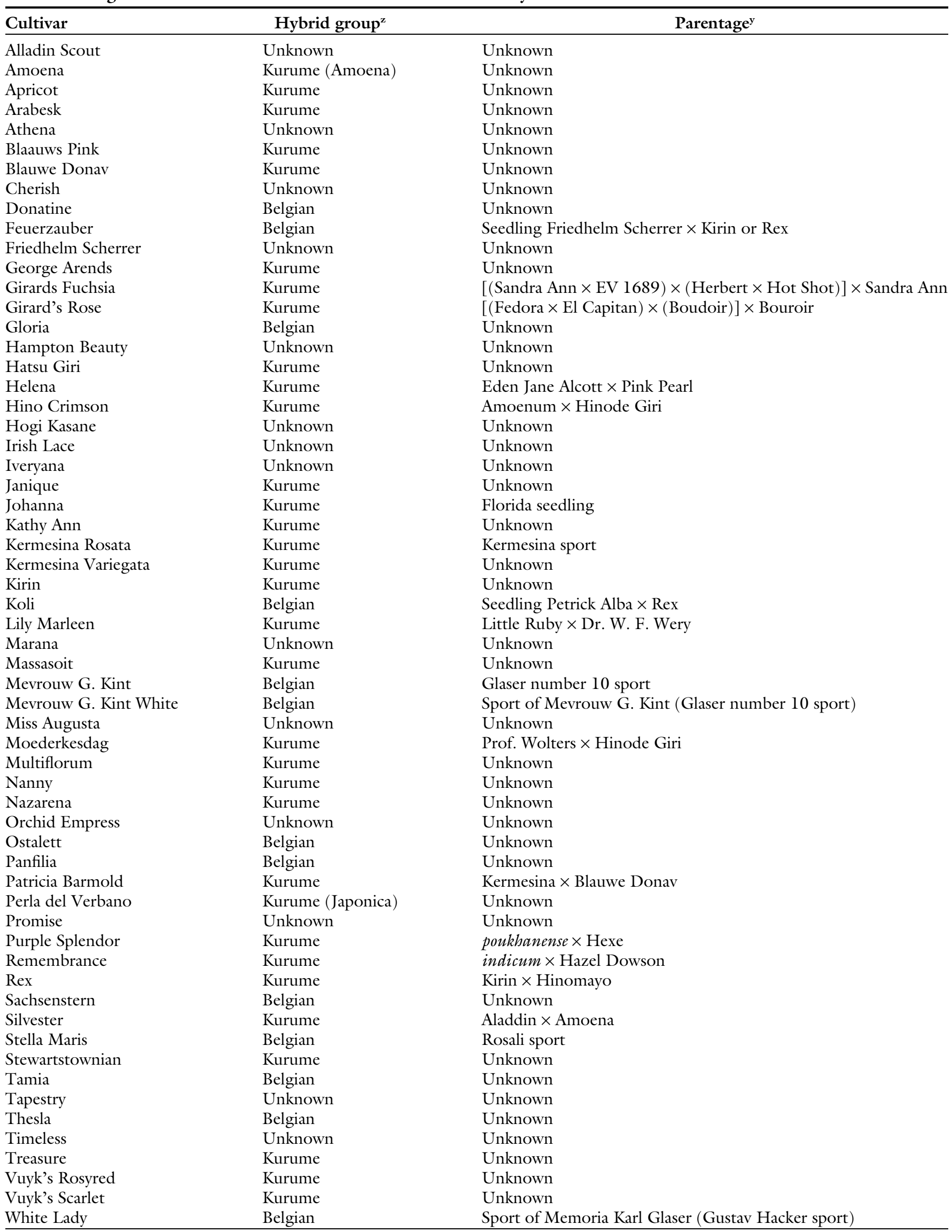

${ }^{2}$ The hybrid group follows the classification reported in Galle (1987).

the parentage follows the classification reported in Galle (1987). 
inoculated with a spore and mycelium suspension $\left(10^{5} \mathrm{cfu} / \mathrm{mL}\right)$ of C. $a c u-$ tatum prepared from 20 -d-old cultures grown on potato dextrose agar maintained at $20 \pm 1{ }^{\circ} \mathrm{C}$. In the first trial, azaleas were inoculated with an isolate of C. acutatum isolated from infected 'Palestrina' azalea. In the second trial, a mixture of three isolates of the same fungal species from infected specimens of azalea 'Palestrina', 'Fior di Pesco Cavadini', and 'Addy Wery' were used. Fifteen milliliters of the spore and mycelium suspension were applied using a manual sprayer to inoculate each plant, thoroughly coating all the leaves. Plants inoculated with deionized water served as controls. Inoculated and noninoculated plants were held inside the greenhouse in a highhumidity chamber for $3 \mathrm{~d}$ after inoculation at 16.5 to $26.5^{\circ} \mathrm{C}$ (average, $18.9-19.5^{\circ} \mathrm{C}$ ) and $61.3 \%$ to $75.8 \%$ relative humidity. Plants were then placed on a greenhouse bench. Relative humidity and air temperature values were measured by a data logger (Fourier Systems, New Albany, IN) placed among the plants.

Disease ASSESSMENT AND Statistical analysis. Disease development was evaluated daily, starting at the first appearance of symptoms. The number of leaf lesions was counted randomly on 15 leaves per plant. Most tested cultivars $(85.7 \%)$ failed to develop disease symptoms and were considered resistant (no leaf spotting present in trials 1 and 2) to C. acutatum (Table 1 ). The average number of spots per leaf was calculated for each susceptible cultivar (Table 2), and data collected were subjected to analysis of variance. Means were separated by the LSD test (SPSS for Windows version 11.0.1; SPSS, Chicago). Symptomatic cultivars were grouped into three susceptibility classes: moderately susceptible (average number of spots/leaf, 0.15 ), susceptible (average number of spots/leaf, 5.1-20), and highly susceptible (average number of spots/ leaf, $>20$ ).

\section{Results and discussion}

The inoculation method used resulted in consistent expression of plant symptoms, which developed within $3 \mathrm{~d}$ of inoculation on the most susceptible cultivars. Sixty of the tested cultivars $(85.7 \%)$ were resistant to C. acutatum (Table 1). Only seven of the cultivars (10\%) developed severe anthracnose symptoms: 'Addy Wery', 'Fior di Pesco Cavadini', 'Geisha Orangerot', 'Kermesina', 'Orion', 'Palestrina', and 'Snow' (Table 2). 'Conversation Piece', 'Eikan', and 'Martha Hitchcock' (4.3\% of the tested cultivars) showed moderate susceptibility (Table 2). The only significant difference between the two experiments carried out was for 'Snow', which was susceptible in the first trial and highly susceptible in the second trial. There is no apparent connection between degree of susceptibility and common parents (when known). Among the Kurume group there are susceptible cultivars, such as 'Addy Wery' and 'Palestrina', and resistant cultivars, such as 'Arabesk' and 'Hino Crimson'. 'Snow' was one of the most susceptible to $C$. acutatum under our conditions, even though this cultivar was the most resistant in a 1958 trial performed in the United States (Stathis and Plakidas, 1958). Such discrepancy may suggest either variability in susceptibility of 'Snow' to different Colletotrichum species or the diffusion of new, more aggressive $C$. acutatum strains.

During the past 3 years, the development of anthracnose on azalea in Italy caused severe financial losses to the industry in the Lake Maggiore area, where production of this species is concentrated. However, our results have demonstrated that among the more popular azalea cultivars grown in the Piedmont region, the majority are resistant to anthracnose. This provides growers a good range of choice when selecting plant material to grow, without having to incur unnecessary risk resulting from losses from the cultivation of highly susceptible cultivars. The variability of Colletotrichum species (Abang et al., 2006; Denoyes et al., 2003; Sreenivasaprasad and Talhinhas, 2005) and the possibility for Colletotrichum species to infect the same

Table 2. Evergreen azalea cultivars susceptible to anthracnose incited by Colletotrichum acutatum.

\begin{tabular}{|c|c|c|c|c|c|c|}
\hline \multirow{4}{*}{$\begin{array}{l}\text { Cultivar } \\
\text { Addy Wery } \\
\text { Conversation Piece }\end{array}$} & \multirow{4}{*}{\begin{tabular}{l}
\multicolumn{1}{c}{ Hybrid group } \\
Kurume \\
Satsuki
\end{tabular}} & \multicolumn{4}{|c|}{$\begin{array}{c}\text { Average leaf spots }(\text { no. })^{y} \text { and susceptibility } \\
\text { class }^{\mathrm{x}}\end{array}$} & \multirow{3}{*}{$\begin{array}{r}\text { Parentage }^{\mathrm{w}} \\
\text { Malvatica } \times \text { Flame }\end{array}$} \\
\hline & & \multicolumn{2}{|c|}{ Trial 1} & \multicolumn{2}{|c|}{ Trial 2} & \\
\hline & & $11.1 \mathrm{bc}$ & $S$ & $8.3 \mathrm{abc}$ & $\mathrm{s}$ & \\
\hline & & $1.0 \mathrm{a}$ & MS & $4.8 \mathrm{ab}$ & MS & $\begin{array}{l}(\text { Emile Russave } \times \text { Carol }) \\
\quad \times \text { Eikan }\end{array}$ \\
\hline Eikan & Satsuki & $1.3 \mathrm{a}$ & MS & $2.4 \mathrm{a}$ & MS & Asahi Zuru seedling \\
\hline $\begin{array}{l}\text { Fior di Pesco } \\
\quad \text { Cavadini }\end{array}$ & Kurume (Japonica) & $17.3 \mathrm{c}$ & $S$ & $13.4 \mathrm{bcd}$ & $S$ & Unknown \\
\hline Geisha Orangerot & Kurume & $11.9 \mathrm{bc}$ & $S$ & $17.0 \mathrm{~cd}$ & $S$ & Unknown \\
\hline Kermesina & Kurume & $10.3 \mathrm{abc}$ & $S$ & $17.1 \mathrm{~cd}$ & $S$ & Unknown \\
\hline Martha Hitchcock & Satsuki & $1.2 \mathrm{a}$ & MS & $1.4 \mathrm{a}$ & MS & $\begin{array}{l}\text { Mucronatum } \times \\
\text { Shinnyo no Tsuki }\end{array}$ \\
\hline Orion & Kurume & $10.2 \mathrm{abc}$ & $S$ & $19.9 \mathrm{~d}$ & $S$ & Unknown \\
\hline Palestrina & Kurume & $6.7 \mathrm{ab}$ & $S$ & $21.4 \mathrm{~d}$ & $S$ & Kaempferi $\times$ J.C. van Tol \\
\hline Snow & Kurume & $18.3 \mathrm{c}$ & $S$ & $33.6 \mathrm{e}$ & HS & Unknown \\
\hline
\end{tabular}

${ }^{2}$ The hybrid group follows the classification reported in Galle (1987).

y Data were subjected to analysis of variance and least significant difference test. Values followed by the same letter are not significantly different $(P \leq 0.05)$.

${ }^{x}$ MS, moderate susceptible (average number of spots, 0.1-5); S, susceptible (average number of spots, 5.1-20); HS, highly susceptible (average number of spots, $>20$ ).

whe parentage follows the classification reported in Galle (1987). 
host (Howard et al., 1992), suggest that the susceptibility of azalea cultivars to anthracnose be monitored and also that Colletotrichum species isolated in nurseries be monitored to determine whether resistant strains are developing.

\section{Literature cited}

Abang, M.M., R. Asiedu, P. Hoffmann, G.A. Wolf, H.D. Mignouna, and S. Winter. 2006. Pathogenic and genetic variability among Colletotrichum gloeosporioides isolates from different yam hosts in the agroecological zones in Nigeria. J. Phytopathol. 154:51-61.

Benson, D.M. and J.L. Williams-Woodward. 2001. Azalea diseases, p. 81-88. In: R.K. Jones and D.M. Benson (eds.). Diseases of woody ornamentals and trees in nurseries. APS Press, St Paul, MN.

Denoyes, R.B., G. Guérin, C. Délye, B. Smith, D. Minz, M. Maymon, and S.
Freeman. 2003. Genetic diversity and pathogenic variability among isolates of Colletotrichum species from strawberry. Phytopathology 93:219-228.

Ellis, J.B. and B.M. Everhart. 1895. New species of fungi. Torrey Bot. Club Bul. 22:434-440.

Farr, D.F., G.F. Bills, G.P. Chamuris, and A.Y. Rosman. 1989. Fungi on plants and plant products in the United States. APS Press, St Paul, MN.

Galle, F.C. 1987. Azaleas. Timber Press, Portland, OR.

Garibaldi, A., D. Bertetti, O. Vinnere, and M.L. Gullino. 2004. Presence of Colletotrichum acutatum causing leaf spot on Azalea japonica in Italy. Plant Dis. 88:572 (abstr.).

Howard, C.M., J.L. Maas, C.K. Chandler, and E.E. Albregts. 1992. Anthracnose of strawberry caused by the Colletotrichum complex in Florida. Plant Dis. 76:976-981.

Rabbogliatti, I. 2004. Il distretto floricolo del Lago Maggiore: Situazione attuale e prospettive future. Proc. Symp. L'azalea, nuovi orizzonti nella ricerca, nella produzione e nell'impiego. p. 14-19.

Scariot, V. 2006. The DNA-typing of ornamental plants: Evergreen azaleas (Rhododendron spp.) and old garden roses (Rosa spp.). University of Turin, Italy, PhD Diss.

Sreenivasaprasad, S. and P. Talhinhas. 2005. Genotypic and phenotypic diversity in Colletotrichum acutatum, a cosmopolitan pathogen causing anthracnose on a wide range of hosts. Mol. Plant Pathol. 6:361-378.

Stathis, P.D. and A.G. Plakidas. 1958. Anthracnose of azaleas. Phytopathology 48:256-260.

Vinnere, O., J. Fatehi, S.A.I. Wright, and B. Gerhardson. 2002. The causal agent of anthracnose of Rhododendron in Sweden and Latvia. Mycol. Res. 106:60-69.

Von Arx, J.A. 1957. Die arten der gattung Colletotrichum Cda. Phytopathol. Z. 29:413-468. 